\title{
Cultural Imperialism in English Medium Schools: A Critical Insight
}

\author{
DR. MUHAMMED SHAHRIAR HAQUE \& TAHMINA AKTER
}

\begin{abstract}
English medium schools in Bangladesh, particularly in Dhaka are providing an alternative form of private education at the primary, secondary and higher secondary levels. However, it cannot be denied that such schools are generally unregulated by any national education boards or monitoring bodies in terms of their syllabus, recruitment policy, admission procedures or their tuition fee structure. Consequently, they enjoy a kind of autonomy like no other education system in Bangladesh. English medium schools on the one hand may be contributing towards the rise of English and the standard of English medium education; on the other hand, they seem to be gradually fostering western culture that undermines Bangladeshi culture and tradition. It seems that cultural imperialism is still continuing in this country through such institutions (see Haque, 2009). Students of English medium schools tend to learn about western tradition, literature, geography, history, socio-political background, and lifestyle, without emphasizing Bangladeshi way of life. The overexposure to western culture could have repercussions in the long run (see Al-Quaderi, 2010).
\end{abstract}

\subsection{Introduction}

In today's world, English is synonymously linked with development, modernity, scientific and technological advancement (Phillipson, 1992, p. 11). In general, the conscious people are aware of this reality (see Tickoo, 2006). After the Liberation War of 1971, the use and the teaching and learning of English became somewhat restricted in Bangladesh; it was the elite groups of the society who were interested in the establishment of English Medium Schools (Hasan 2004). In the last 30 years or so, English medium schools have mushroomed up in many places in Bangladesh, 
especially Dhaka. Since English medium education is very expensive, it is generally the upper class of the society who can afford such education; and parents are very eager to give their children such education as it opens up a world of opportunities (Banu and Sussex 2001). Furthermore, parents prefer English medium education for their children because it is a sign of status and prestige (Tickoo 2006).

\subsection{Critical Implication}

Every language is associated with a culture (Iredale in Phillipson 1992, p.11). Modiano (2001) believes that "English virtually Anglo-Americanizes the non native speaker" (p. 2). So, from that perspective, the students of English medium schools in Bangladesh are frequently exposed to western culture instead of Bangladeshi culture (Al-Quaderi, 2010). Such overindulgence of western culture in the forms of their life styles, attitudes, ideologies belittles Bangladeshi traditional way of life (ibid.; see Crystal, 1997), and leads towards globalization, which Chang (2004) says is another name for westernization. Consequently, students of English medium schools decrease their use of Bangla, and gradually become detached from the Bangladeshi culture as well (see Haque, 2009). Gradually they start to practice western culture at the expense of their own tradition and culture.

Phillipson (1992) says that English language is replacing or displacing other languages (p. 27). Yet, it cannot be denied that English medium schools in Bangladesh are providing an alternative form of private education at the primary, secondary and higher secondary levels. However, the manner in which English is taught may be debatable and/or questionable. According to Haque (2009), English medium schools do not help to practice Bangladeshi culture when teaching the English language and therefore seems to be culturally imperialistic. The students of such schools follow British curriculum and read books based on foreign context, particularly western culture. As a result, students of English medium schools in Bangladesh, learn about western tradition, geography, history, political and cultural background, leaving out Bangladeshi resources (e.g. 
literature, history, culture and so on) (Haque, 2009). Haque (2009) says that foreign culture is introduced in much more appealing and attractive ways than local culture; consequently students adopt such culture. For example the students of EMSs learn much more about William Shakespeare than Robindranath Tagor or Kazi Nazrul (ibid). The British Council provides syllabi for O-level and A-level exams, that is, for standards/classes IX-XII; it does not provide any kind of syllabi whatsoever for any of the other standards/classes - pre and primary school. The EMSs can teach whatever they desire up to standard/class VIII. Neither The British Council nor the Government or any of its monitoring body monitors the curriculum, the quality of education, the textbooks, the exams, the recruitment policies of teachers and staff, the cultural practices, and so forth of English medium schools in Bangladesh. Due to such oversight or overindulgence of autonomy, cultural imperialism seems to be occurring in EMSs.

The intention of this paper is to explore how cultural imperialism is occurring in English medium schools in light of Phillipson (1992), Canagarajah (1999) and Modiano's (2001) concepts of cultural/linguistic imperialism. The implication of a research of this nature is significant in the sense that the findings enable us to emphasize the so-called innocence of such (English medium) schools that implicitly propagate cultural imperialism under the guise of modern education.

\subsection{Cultural/Linguistic Imperialism}

According to Phillipson (1992: 44-46) the term 'imperialism' can have many meanings for instance political imperialism, economical imperialism, racial imperialism, social and ideological imperialism and so on. Tomlinson (1991) feels that imperialism is the process that operates by controlling economic, political, cultural systems of the whole world (p. 15). The dominating countries usually prescribe the norms regarding appropriate cultural etiquette, that is how people should run business, what should be fair politics, how people should dress, even how people should think, and so on (ibid.). Tomlinson (1991) further says that imperialism is a silent 
process which is accelerated by the cultural influences of dominating countries; at one time colonization was the tool of imperialism, but now it is capitalism. Phillipson (1992) believes that, imperialism is now going hand in hand with capitalism. Though imperialism at one time was synonymous with the 'British Empire', nowadays it seems to be synonymous with the Western world, particularly American and British capitalism (see Phillipson 1992; Pennycook, 1994). According to Crystal (1997), the present importance and dominance of English language is the result of two factors - the rise of the British colonial power up to the end of nineteenth century and the emergence of economic power of the United States in the twentieth century (p. 53).

The nature of imperialism has changed; it has transcended from explicit military might to economic, educational, cultural and linguistic dimensions. However, the implicit trends of such imperialistic nature can be traced to more than one and a half centuries ago in Macaulay's parliamentary speech, where he mentioned that the British people wanted to establish economic, educational, linguistic and cultural empire in the Indian subcontinent (Young, 1957). The British wanted to explore the supremacy of their language, literature, science, technology and so on, and for this, they wanted to form a group of people who would be 'Indian in blood and colour but English in taste, in opinions, in morals and in intellect' (ibid). To some extent this could be occurring in English medium schools as well.

\subsection{Linguistic Imperialism}

Language is an important medium for expressing oneself, and in many countries, it contains a nation's cultural, traditional and exclusive flavours. Crystal (1997) explains that for various reasons (e.g. political, economic, cultural, power domination, etc.) some languages turn out to be more dominant than others, for instance English (p. 5); while Tomlinson (1991) thinks that when a language becomes powerful, it replaces the other languages. In the linguistic competition, English came out on top and dominated other languages (e.g. French, German) and ultimately gained 
the status of international language since the Second World War (Baugh and Cable, 1993, p. 7-8). Now, since English is the global language (Crystal 1997), Phillipson (1992) feels that it is explicitly imperialistic in nature. Linguistic imperialism may be defined as the dominance of one language over others (p. 47). Phillipson (1992) elaborates that because of the language policy of the inner circle countries (based on Kachru's concentric circles), the languages of the periphery countries are being displaced or are at stake. According to Kachru $(1985,1986)$, the BANA (Britain, Australia, North America) countries are centres, and the other countries like Bangladesh, India, China, and so forth are peripheral countries.

\subsection{Cultural Imperialism}

Cultural imperialism can be discussed with respect to the term 'anglocentricity' which means, the other languages and cultures will be measured keeping in terms of the English language and its culture; consequently, other cultures are thought to be inferior (Phillipson, 1992). According to Canagarajah (1999), less developed countries depend on the developed countries, (i.e. western countries) for educational materials, methodology, expertise, and so on, which propagate cultural ideologies of the western countries. Phillipson (1992) says that the base of cultural imperialism is linguistic imperialism; hence, if a language is neglected, the culture of its native speakers is also neglected (p. 53). A language is not merely a language; it is mingled with culture. Cultural imperialism occurs silently through the exploration of ideas, theories and experiences, publication and so on (Phillipson, 1992, p. 57-58). Phillipson (1992) quotes the Director General of the British Council who said, "Britain's real black gold is not north sea oil but the English language". The explanation of this statement can be found in Iredale's words (in Phillipson, 1992):

... when people learn English, for whatever purpose and by whatever method, they acquire something of the flavour of our culture, our institutions, our ways of thinking and communication. (p. 11) 
Phillipson (1992) thinks that the promotion of British book-trade, which explores the centre's (Kachru's concentric circle, 1986) ideology and thought, is a remarkable medium of cultural imperialism. These books presents the ideas, attitudes, activities which are the cultural element of the 'centre' and thought to be the model for peripheral countries (Phillipson, 1992, p. 61). Therefore, in that sense, English language teaching (ELT) could have hidden agenda, because through such teaching, the ideology and the culture of the native English speakers could be propagated to displace, replace and encompass the culture of other communities.

\subsection{History of linguistic and cultural Imperialism in Bangladesh}

Mcleod (in Rahman et al., 2010, p. 116) says that, Bangladesh was under Indian subcontinent which was under British rule from 1757-1947. It was the European missionaries and East India Company who established some educational institutions (Phillipson, 1992, p. 110-112). The imperialistic education began from the period of British colonization, that is, early $19^{\text {th }}$ century (Rahman et al., 2010). At the beginning of 19th century, the English language schools based on British model were established in the region, which is now Bangladesh (Ali et al. in Rahman et al., 2010). Only those Indians who were proficient in English were recruited under the government job (Phillipson, 1992, p.111). At the end of first half of $19^{\text {th }}$ century, British rulers had a wish to make this continent a field of trade and business rather than a house of slaves (Young, 1957). Therefore, they started to concentrate on education of the natives, but the medium of education was English (ibid). Kumar (in Rahman et al., 2010) says that the British colonial officials wanted to teach Indian people making English the medium of instruction so that they can explore their (western) language, literature, science and technology. Thomas B. Macauly passed an important resolution in 1835 with the goal to teach some Indians who retain their Indianness in blood and colour but British in taste and ideology (Young, 1957, p. 716-18). The hidden agenda of the British was to create some socalled British elites who would be Britain's future customers, particularly in terms of their language and culture (see Rahman et al., 2010). After 
Macaulay's resolution, the promotion of English was accelerated by political, economic and social power; thus, the seed of linguistic and cultural imperialism was sown (Phillipson, 1992, p. 110-113).

\subsection{Streams of education}

There are three streams of education in Bangladesh (Kamol, 2009; Rahman et al., 2010):

1. Mainstream Bangla medium

2. English medium

3. Madrasha medium

In Mainstream Bangla medium, the medium of instruction and education is Bangla (Kamol, 2009). Most of the students of Bangladesh fall under this stream (Banu and Sussex, 2001, p. 130). There are two categories under Bangla medium: Public and Private. However each category has a primary, secondary (S.S.C) and higher secondary (H.S.C) level (Haque, 2011, p.185). Public schools and colleges provide only Bangla medium education but private Bangla medium schools and colleges provide both Bangla and English versions of the syllabus provided by the board; and it is mentionable here that there are six educational boards of Bangladesh (ibid.). English Medium system is a special kind of education system run by private ownership where the medium of instruction is English. As mentioned earlier, these schools are not monitored by any of the government authorities in terms of their syllabus, recruitment policy, admission procedures or their tuition fee structure. These schools directly follow the British curriculum and syllabus (Haque, 2011, p. 185). The students of English medium schools have to pass O-Level or Junior Cambridge and A-Level or Senior Cambridge exams to enrol in the universities (ibid). After passing from schools, most of these students study in the private universities or go abroad (Banu and Sussex, 2001; Ainy, 2001). English medium education is chosen by the elite group of the society who 
do not want their children to lag behind in the era of globalization and especially when English can bring them good jobs, opportunities of scholarships and so on (Ainy, 2001, p. 114; Banu and Sussex, 2001, p. 130).

\subsection{English medium education in Bangladesh}

After the independence in 1971, guided by the thought of nationality and love for mother tongue, the government banned English medium schools, and they were completely removed from Bangladesh in 1972 (Banu and Sussex, 2001, p. 129-31). However, English could not be removed from universities because the class lectures were needed to be given in English and the books and journals were all in English (ibid.). On the other hand, the elite group of the society started to feel the necessity of English, and consequently English medium schools started to emerge again (Ainy, 2001). As English was not emphasized in public Bangla medium schools, the English medium schools started to grow day by day, with the growing demand of English in every sector (Rahman et al., 2010, p. 117; Ekushe, English and Ethics, 2010). Since the 1980s English medium schools, which are all privately funded, have been mushrooming in Bangladesh, especially in Dhaka (see Banu and Sussex, 2001).

English medium schools in Bangladesh can be traced back at the beginning of the $19^{\text {th }}$ century (Rahman et al., 2010, p. 116). The students of such schools follow the British curriculum and syllabus directly (Haque 2009). They read imported western books written for the western context (Al-Quaderi, 2010). After reading these books, the students become familiar with western geography, history, literature, western way of life and their ideology (ibid). Consequently, they do not get to know about Bangladeshi culture, for example, they are much more familiar with Shakespeare than Robindronath Tagore (Haque, 2009). Western ideologies and values are explored through the books and curriculum of British council but there is no mention of Bangladeshi culture and Bangladeshi resources (Kamol 2009; Haque, 2009, p. 13; Ekushe, English and Ethics 2010; Al-Quaderi, 2010). 


\subsection{Methodology}

The research follows a descriptive and qualitative paradigm. According to Kamol (2009), there are approximately 500 English medium schools in Bangladesh. The number might be larger than this in reality. However, among the 162 registered English medium schools under the British Council situated in Dhaka, there are 18 such schools in Uttara, Dhaka. From these 18 schools, ten were selected for data collection. Data was collected from both the students and the teachers through questionnaire and interviews respectively. 400 students of class V and VI were chosen for the questionnaire survey, and 20 teachers were interviewed for the study.

\subsection{Theoretical Framework}

The research was carried out focusing on Phillipson's (1992) theory of linguistic and cultural imperialism. Phillipson (1992), who believes culture is a country's intellect, art, science, education, invention, history, national personality, past history and present way of life, says that linguistic imperialism is the basic component of cultural imperialism. Likewise, Canagarajah (1999) believes that there is a deep relationship between language and culture, while Modiano (2001) believes that foreign language learning is related to cultural violation and/or invasion. Based on these three assumptions, the study sought to explore whether the national and official language, Bangla, is neglected in English medium schools, due to the overwhelming influence of the foreign language, English. If so, it may be perceived that the Bangladeshi culture is also neglected, in English medium schools. Phillipson's (1992) theory of linguistic and cultural imperialism is applied for peripheral country like Bangladesh, which is, based on Kachru's (1986) concentric circles.

\subsection{Setting and Sampling}

The setting was very important in this research. The survey was conducted in classroom setting to collect data from the students instantly so that the information or answer is only from them rather than from their 
parents or anybody else. Teachers' interviews were taken either at school or outside. Some interviews were recorded based on the permission of the interviewees.

All of the 18 English medium schools from Uttara were considered, but some of the schools did not cooperate. So at last, data was collected from 10 schools. Data was collected from the students of class V and VI because it at this age, the students seem to be very much vulnerable to any type of influence. It is the preliminary stage of their personality. The English teachers of class V and VI were selected for interview. In this study, only one teacher was selected from each class, so one from class $\mathrm{V}$ and another from class VI were interviewed. In total, five hundred questionnaires were given and four hundred were selected and analyzed because some questionnaires were incomplete. The students were given instruction both in Bangla and English. The teachers' interviews were taken in English. Twenty teachers from ten schools were interviewed. Data was collected from different schools in Dhaka from December 2010 to February 2011.

\subsection{Findings and Discussion}

More and more people in Bangladesh seem to be interested in English medium education, because good knowledge of English provides many windows of opportunities. Numerous people tend to view western culture synonymously with modern culture (see Al-Quaderi, 2010). Therefore, when they learn English, they seem to welcome the culture as well. It seems that the students of English Medium Schools could be victims of cultural imperialism (ibid.). This paper sought to find out whether cultural imperialism is occurring in English medium schools. If so, what factors are propagating such a phenomenon? The findings are discussed below.

\subsection{Findings in terms of Questionnaire Survey}

There were seventeen questions in the students' questionnaire of which four were open ended and thirteen were close ended. In response to the question number one (Table 1) out of 400 students, 380 (that is, 95\%) 
students answered 'English' (Table 1). They said they study in English medium schools, so they should always practice in English for being better speaker and added that Bangla is prohibited in the school premises. The remaining 5\% said, they use both English and Bangla. They use Bangla when they have difficulty in expressing something in English.

For the second question, out of 400 students, 340 (85\%) students said that their teachers told them to speak in English outside the classroom (Table 1). 60 students or $15 \%$ said that their teachers do not suggest them to use any specific language outside the classroom.

In response to the question three, $312(78 \%)$ of 400 (Table 1) students said their parents want them to use English at home. Here it is mentionable that, during Parents' Day or other occasions whenever the teachers get to meet the parents, they suggest the parents to tell their children to use English at home. Sixty-four (16\%) students said that their parents do not suggest what language they should use at home. The remaining $24(6 \%)$ students said that their parents want them to use Bangla at home. The reason for this might be the parents do not want to get their children detached from Bangla language or they (parents) are not good in English, that is, they have difficulty in interacting in English with their children.

In replying to question four, most of the students (76\%) wrote the names of only English poems, while $24 \%$ wrote the names of both Bangla and English poems. Not even a single student wrote names of only Bangla poems (Table-1).

Similarly, when they were asked about their favourite story in question five, most of the students (84.25\%) wrote the names of English stories. Very few of them (11\%) (Table 1) wrote the names of both Bangla and English stories. However, unlike the previous question, 19 students $(4.75 \%)$ wrote the names of only Bangla stories. These students might have come from Bangla medium background. It was revealed that most of the students read English stories, may be because they cannot read Bangla properly or they are not exposed to Bangla that much. 
Students were asked to write the names of some of their favourite TV programs in question six. In response, $68.25 \%$ (273 in number) students wrote programmes from the English channels like Ten Sports, HBO, CNN, Star Movies, Star Sports and so on (Table-1). In the movie channels, predominantly western (American and British) movies are shown. Other $(26 \%)$ students wrote that they watch western, Indian and Bangladeshi programmes and only a few $(5.75 \%)$ students wrote they watch only Bangladeshi programmes.

In terms of dress or cloths, majority of the students wrote they like western dress. Whether they are boys or girls, when the question of choice comes, they like western dress. It is reflected through their answers in the question seven that most of the students ( $81.25 \%$ ) placed only western dress in their choice list while $(17.5 \%)$ placed both Bangladeshi and western dress (Table-1). Very few of them (1.25\%) wrote they like only sharee, panjabi, salwar-kamiz, and so on.

When the students were asked to list their favourite food in the question eight, most of them wrote the names of fast food like pizza, chicken fry, burger, and so forth, but they hardly mentioned any Bangladeshi food, for instance, pitha. From 400 students, 344 students (86\%) wrote solely western foods (Table-1) and remaining 56 students (14\%) placed Bangladeshi food with some western foods in their choice list.

\section{Table 1: Summary of the Questionnaire Survey}

\begin{tabular}{|l|l|l|l|l|}
\hline Questions & NR $^{1}$ & Percentage & Response & Reason \\
$\begin{array}{l}\text { 1. Which } \\
\text { language do } \\
\text { you speak in } \\
\text { the class? }\end{array}$ & 380 & $95 \%$ & English & $\begin{array}{l}\text { They are in English } \\
\text { medium school and } \\
\text { Bangla is } \\
\text { prohibited in the } \\
\text { school premises }\end{array}$ \\
\hline
\end{tabular}

${ }^{1} \mathrm{NR}=$ Number of Respondents/Teachers 


\begin{tabular}{|c|c|c|c|c|}
\hline & 20 & $5 \%$ & $\begin{array}{l}\text { Both English } \\
\text { and Bangla }\end{array}$ & $\begin{array}{l}\text { Sometimes they } \\
\text { have difficulties in } \\
\text { expressing in } \\
\text { English }\end{array}$ \\
\hline $\begin{array}{l}\text { 2. Which } \\
\text { language do } \\
\text { your } \\
\text { teachers } \\
\text { suggest you } \\
\text { to use } \\
\text { outside the } \\
\text { classroom? }\end{array}$ & 340 & $85 \%$ & $\begin{array}{l}\text { English } \\
\text { language }\end{array}$ & \\
\hline $\begin{array}{l}\text { 3. Which } \\
\text { language do } \\
\text { your parents } \\
\text { want you to } \\
\text { use at home? }\end{array}$ & 24 & $6 \%$ & $\begin{array}{l}\text { English } \\
\text { language } \\
\text { Do not } \\
\text { suggest any } \\
\text { language } \\
\text { Bangla } \\
\text { language }\end{array}$ & $\begin{array}{l}\text { a) Parents' } \\
\text { motivation by the } \\
\text { teachers } \\
\text { b) Parents' } \\
\text { fascination towards } \\
\text { English }\end{array}$ \\
\hline $\begin{array}{l}\text { 4. Do you } \\
\text { read poems? } \\
\text { Would you } \\
\text { name some } \\
\text { of your } \\
\text { favorite } \\
\text { poems? } \\
\text { Bangla } \\
\text { English or } \\
\text { others }\end{array}$ & 304 & $76 \%$ & $\begin{array}{l}\text { They (the } \\
\text { students) } \\
\text { wrote the } \\
\text { names of } \\
\text { only English } \\
\text { poems }\end{array}$ & \\
\hline
\end{tabular}




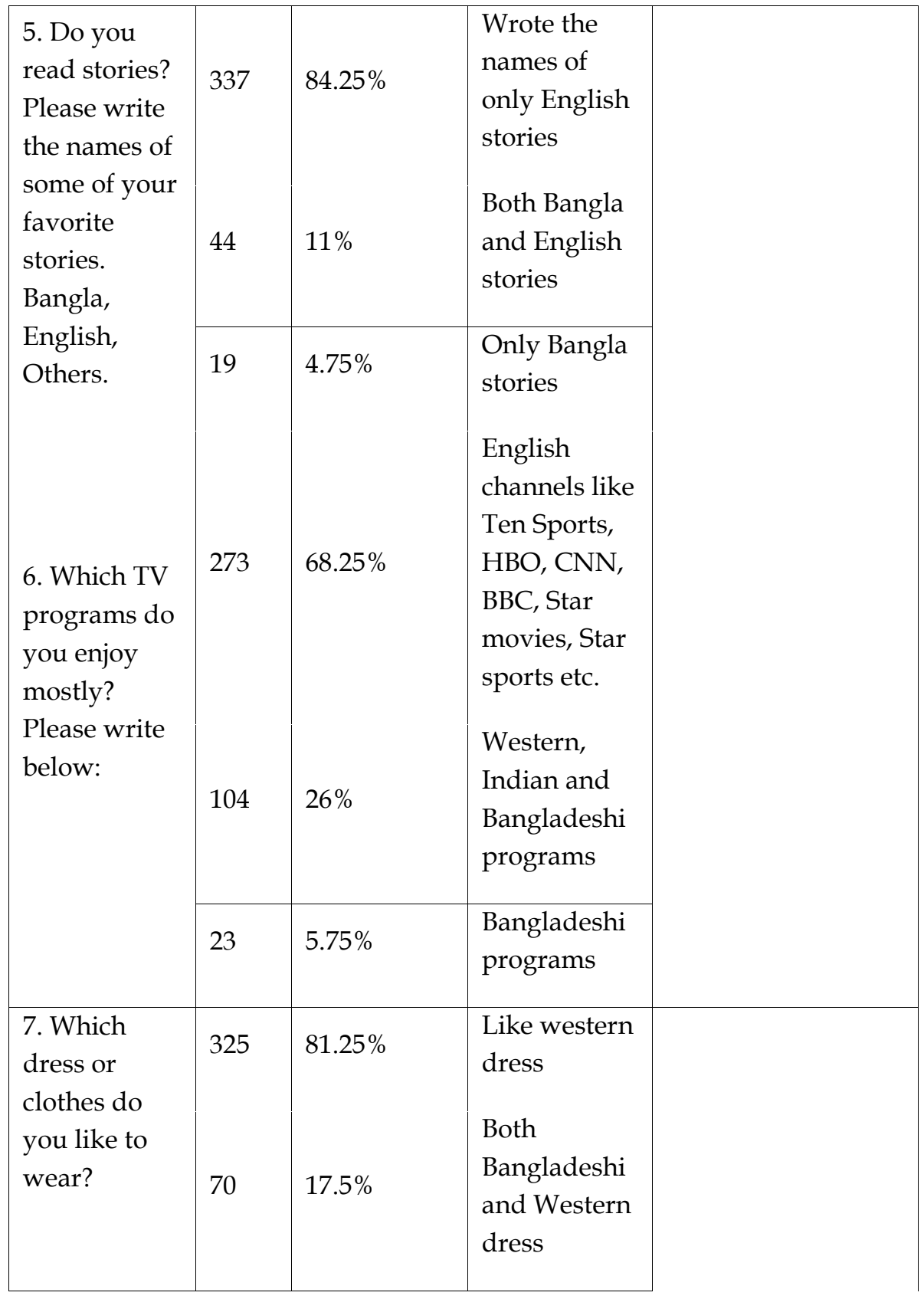




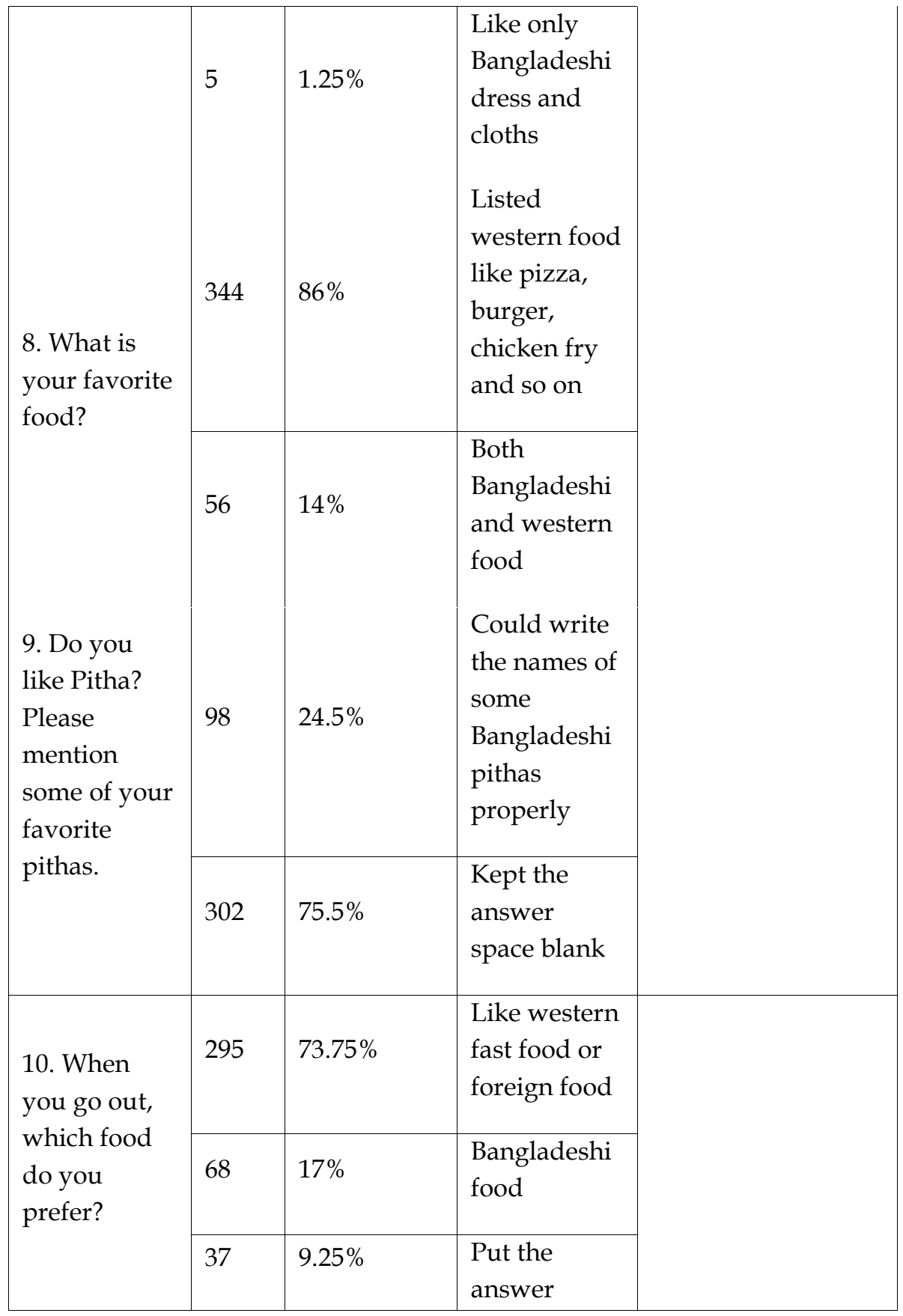




\begin{tabular}{|c|c|c|c|c|}
\hline & & & space blank & \\
\hline \multirow{2}{*}{$\begin{array}{l}\text { 11. Do you } \\
\text { use greeting } \\
\text { cards? If yes, } \\
\text { which cards } \\
\text { do you use? }\end{array}$} & 310 & $77.5 \%$ & $\begin{array}{l}\text { Use English } \\
\text { greeting } \\
\text { cards }\end{array}$ & $\begin{array}{l}\text { Bangla cards are } \\
\text { not that much } \\
\text { available }\end{array}$ \\
\hline & 76 & $19 \%$ & $\begin{array}{l}\text { Both Bangla } \\
\text { and English } \\
\text { cards }\end{array}$ & $\begin{array}{l}\text { They feel } \\
\text { comfortable with } \\
\text { English }\end{array}$ \\
\hline $\begin{array}{l}\text { 12. Which } \\
\text { language do } \\
\text { you use to } \\
\text { write in } \\
\text { cards? }\end{array}$ & 14 & $3.5 \%$ & $\begin{array}{l}\text { Want to buy } \\
\text { Bangla cards } \\
\text { but not } \\
\text { available }\end{array}$ & \\
\hline \multirow[b]{2}{*}{$\begin{array}{l}\text { 13. a) Which } \\
\text { subject(s) in } \\
\text { your class do } \\
\text { you find } \\
\text { easy? }\end{array}$} & 313 & $78.25 \%$ & English & \\
\hline & 87 & $21.75 \%$ & $\begin{array}{l}\text { Science, } \\
\text { Maths, } \\
\text { Geography, } \\
\text { Religions } \\
\text { studies }\end{array}$ & \\
\hline $\begin{array}{l}\text { 13.b) Which } \\
\text { subjects are } \\
\text { difficult? }\end{array}$ & 320 & $80 \%$ & $\begin{array}{l}\text { Bangla } \\
\text { Maths, } \\
\text { History, } \\
\text { Geography }\end{array}$ & \\
\hline $\begin{array}{l}\text { 14. a) Which } \\
\text { days do you } \\
\text { celebrate } \\
\text { greatly? } \\
\text { Please tick } 7\end{array}$ & 310 & $77.5 \%$ & $\begin{array}{l}\text { Chose more } \\
\text { western } \\
\text { terms and } \\
\text { phrases than } \\
\text { Bangladeshi } \\
\text { ones }\end{array}$ & \\
\hline
\end{tabular}




\begin{tabular}{|c|c|c|c|}
\hline $\begin{array}{l}\text { days you } \\
\text { celebrate the } \\
\text { most. }\end{array}$ & 90 & $22.5 \%$ & $\begin{array}{l}\text { Tick more } \\
\text { Bangladeshi } \\
\text { terms and } \\
\text { phrases than } \\
\text { western ones }\end{array}$ \\
\hline \multirow[b]{2}{*}{$\begin{array}{l}\text { 14. b). Which } \\
\text { two days do } \\
\text { you celebrate } \\
\text { the most or } \\
\text { enjoy? }\end{array}$} & 280 & $70 \%$ & $\begin{array}{l}\text { Enjoyed two } \\
\text { Eids the } \\
\text { most }\end{array}$ \\
\hline & 120 & $30 \%$ & $\begin{array}{l}\text { Gave mixed } \\
\text { terms like } \\
\text { valentine's } \\
\text { day, } \\
\text { Friendship } \\
\text { day, Pohela } \\
\text { Boishak etc. }\end{array}$ \\
\hline \multirow{2}{*}{$\begin{array}{l}15 . \text { Do you } \\
\text { enjoy music? } \\
\text { Which } \\
\text { music? }\end{array}$} & 336 & $84 \%$ & $\begin{array}{l}\text { Hindi and } \\
\text { English } \\
\text { music }\end{array}$ \\
\hline & 64 & $16 \%$ & $\begin{array}{l}\text { Bangla, } \\
\text { English and } \\
\text { Hindi music }\end{array}$ \\
\hline \multirow{2}{*}{$\begin{array}{l}16 . \text { How do } \\
\text { you greet } \\
\text { your } \\
\text { teachers and } \\
\text { seniors when } \\
\text { you meet } \\
\text { them? }\end{array}$} & 340 & $85 \%$ & $\begin{array}{l}\text { ‘Hi' or } \\
\text { ‘Hello' }\end{array}$ \\
\hline & 60 & $15 \%$ & $\begin{array}{l}\text { As-Salamu- } \\
\text { Alaikum }\end{array}$ \\
\hline $\begin{array}{l}\text { 17. Which } \\
\text { words and }\end{array}$ & 349 & 87.25 & $\begin{array}{l}\text { Western } \\
\text { terms }\end{array}$ \\
\hline
\end{tabular}




\begin{tabular}{|l|l|l|l|}
\hline $\begin{array}{l}\text { names are } \\
\text { familiar to } \\
\text { you? }\end{array}$ & 51 & 12.75 & $\begin{array}{l}\text { Both } \\
\text { Bangladeshi } \\
\text { and western } \\
\text { terms }\end{array}$ \\
\hline
\end{tabular}

In response to question nine, only few students $(24.5 \%)$ could write the names of some Bangladeshi pitha like patishapta, chitue, vapa pitha, pakon pitha properly, whereas most of the students $(75.5 \%)$ did not write anything (Table 1). This may suggest a very poor knowledge of pitha and its relation to Bangladeshi culture. Here, the fact could be that, Bangladeshi pithas are not advertised properly in our society, while western food are advertised very attractively in shops, TV programmes and billboards.

In question 10, the students were asked about the food they prefer when they go out. In response, $73.75 \%$ of the students wrote only the names of different types of western fast food or foreign food, while $17 \%$ percent mentioned the names of Bangladeshi food. The remaining $9.25 \%$ students did not write anything.

In case of greeting cards, which deals with question number 11 and 12, most of the students $(77.5 \%)$ said, they like English cards because the cards look attractive and they are more available than the cards written in Bangla (Table 1). When they were asked, why they use English language in cards, they said they feel comfortable writing in English. Some of the students (19\%) said they use both Bangla and English cards. Very few (3.5\%) students said that they want to buy Bangla cards, but they (i.e. Bangla cards) are not always available.

In response to question 13(a), when the students were asked about the subject they find easy, $313(78.25 \%)$ of them mentioned that they found English to be the easiest subject followed by science, maths, geography, religious studies (Table 1). Response to question 13(b) suggests that Bangla is the most difficult subject to the students of English medium schools 
because, based on the data, $80 \%$ students found it hard. This might be because they do not have much exposure to Bangla from their early childhood. Although the other students, that is, the remaining 80 students $(20 \%)$, wrote the names of other subjects like math, history, geography respectively, none of them thinks English is hard.

Question number 14(a) reveals something that is obvious and at the same time is something which is bad for Bangladeshi culture. The students were given 14 terms and phrases, which were taken both from Bangladeshi school books and foreign books taught in English medium schools in our country. The students were told to choose seven terms, which they are familiar with. This question was set with the intention to know whether the students had a western orientation, despite being Bangladeshi citizens and residing in Bangladesh. Most of the students (77.5\%) chose English terms and phrases over Bangladeshi ones (Table 1). Here, the reason why this is bad for Bangladeshi culture is that though most of these students of English medium schools have never been abroad, still they are more familiar with foreign terms than local ones. For example, they know about Easter Sunday and Halloween, but do not know Eid-e-Miladun Nobi. Most of the students know April fool but do not even know about Halkhata. They celebrate Friendship day, Teacher's Day, Father's Day, Mother's Day, Valentine's Day, and so on, leaving out Nobanno, a traditional cultural occasion in Bangladesh. But here it is mentionable that there are some exceptions. The remaining $22.5 \%$ students chose more Bangladeshi terms than western expressions.

When the students were asked in question 14(b) about their most enjoyable occasions, based on question 14(a), they wrote about the two Eids-Eid-Ul-Fitr and Eid-Ul-Azha. Here 70\% of the students (Table 1) said that even though they immensely enjoy the two Eids, they also enjoy Christmas. The reason why they like Christmas might be that it is presented to them in a very appealing and attractive manner in the English medium schools. They read about it in books, it is presented through music, movies, advertisements, and so on. Regarding how the students celebrated the two 
Eids, it was revealed that they pass the days just like other festivals, wearing nice clothes, meeting friends, enjoying the food and the chat sessions. It was also revealed that they do not know the significances or meanings of the two Eids.

In case of music, most of the students (84\%) like to enjoy Hindi and English music rather than Bangla songs (Table-1). The remaining 16\% of the students said they like Bangla, English and Hindi music. However, no one said that they liked Bangla songs the most.

In response to question 16, regarding how they greet their teachers and seniors, most of them (85\%) said that 'hi' or 'hello'. Those who greet with a 'Salam' or 'Asalamwalikum' consisted of $15 \%$ of the students (Table 1). This suggests how westernized the students of English medium schools have become.

In the last question the students were told to choose the familiar terms and phrases. In this question, there were nineteen terms, of which, ten were taken from Bangladeshi context and nine taken from western context. It was found that $87.25 \%$ students were more familiar with the western terms, while the other $12.75 \%$ of the students chose both Bangladeshi and western terms and phrases. For instance, most of the students of English medium schools know about ice-skating, but they do not know about Ha-do-do-our national game. This is because they (the students) have read about iceskating but not about Ha-do-do. Similarly, most of them know King Arthur but only a few of them know Khudirum Bosh. Snowstorm is much more familiar to them than Kalboishakhi.

\subsection{Discussion of the Teachers' interviews}

It has already been mentioned earlier that this is a qualitative research. The interviews of the teachers were analyzed based on thematic information, their mood and attitudes. Through these interviews, the notions of the teachers towards Bangladeshi and western culture was 
compared. Among the 20 English teachers who were interviewed, 10 were from class $\mathrm{V}$, while the other 10 were from class VI.

In response to the first question $80 \%$ of the teachers (Table 2) said, they strictly prohibit the use of Bangla in the classroom, and some of them said that they would even give punishment if English is not used in the classroom. They explained that in an English medium school, there should be an English atmosphere; only then, the students could become very fluent speakers of English. Few teachers (10\%) said that they do not do anything regarding this issue, while a few $(10 \%)$ more said that sometimes they let the students use Bangla in the classroom.

In response to question two, the teachers said that they celebrate different occasions in the school, but majority of the teachers (75\%) said that students like Pohela Boishak the most (Table 2). They said that on this day the students and teachers wear colourful clothes (red and white). The remaining $25 \%$ of the teachers said that the students celebrate other occasions, either in school functions or by themselves, like 21st February, $31^{\text {st }}$ December, Friendship Day, Pohela Falgun, Valentine's Day, April Fool, Christmas Day, $1^{\text {st }}$ January, $16^{\text {th }}$ December, Eid-e Miladun Nobi. Most of the teachers mentioned that even though $31^{\text {st }}$ December is not officially celebrated in schools, students tend to celebrate this night among themselves. When the teachers were asked about $16^{\text {th }}$ December and $21^{\text {st }}$ February, 80\% teachers said, these are holidays; so the students do not do anything in school. The teachers also said that they see the students enjoy a lot on Friendship Day and Valentine's Day.

With regard to the third question, when the teachers were asked about which TV programmes they think the students should watch, $85 \%$ teachers (Table 2) said English channels like Discovery, HBO, National Geography, Star Movies, BBC, CNN, and so on. In explaining why, they said that if the students watch these channels, they can learn better English and at the same time know about the whole world. $10 \%$ teachers said that the students should watch whatever they like, and only $5 \%$ teachers said the students 
should watch Bangla channels so that they get to know more about Bangladesh.

In answering the fourth question, $75 \%$ of the teachers said they do not correlate Bangladeshi cultural with western cultures while teaching (Table 2). Some teachers $(15 \%)$ said that, they cannot go beyond the prescribed texts, because their school systems do not permit this, while some others said that it is time-consuming or they do not want to go beyond the syllabus. They also added that in English medium schools, the teachers are required to submit lesson plans. Therefore, it is very difficult for them to go beyond the lesson plans. Furthermore, the co-ordinators or supervisors have to be convinced about the proposed changes. Sometimes the teachers do not want to make any changes as they might be criticized for changing the previous lesson plans. The interviews revealed that despite the fact that some teachers have soft corner for Bangladeshi culture and tradition, they do not bother too much to change the English syllabus. Some teachers mentioned that it was not their duty to make changes, or co-relate Bangladeshi cultures with foreign cultures, since it is not in the prescribed books. They feel that co-relating Bangladeshi cultures with foreign cultures is not important for the students. They added that it would cost them extra time and the school would not pay them for their efforts. Two teachers (10\%) tried to co-relate Bangladeshi culture with foreign cultures, but due to the systems of their respective schools could not always do so.

In response to question five, $80 \%$ of the teachers think that the students will not face any problem, if they know little Bangla. They explained that without good command of the Bangla language, the students can survive nationally and globally. Some of these teachers even added that, good command over English is necessary in most of the lucrative jobs but good command in Bangla is not that much necessary. Some teachers $(20 \%)$ said that though the students can survive without Bangla, they should learn it because it is their mother tongue, and if they do not learn it now, their next generation will not learn it either. 
The teachers had mixed opinion regarding question six, as $70 \%$ of them said the change in cultural trend is a good sign because the world is advancing and so should we (Table 2). Some of the teachers (20\%) said that the influence of other cultures is not good. They mentioned that though they understand such influences are harmful, they cannot help it, because the students have an obsession for western attire, fast food, and western lifestyle as they think such things represent the modern world. These teachers said that the same thing happens with their own children as well. It is important to mention that the interviews revealed that most of the teachers tend to have a weakness for western culture, and some are even obsessed with it. Though these teachers understand the harmful influences, they do not have the courage to take any initiative. Two teachers $(10 \%)$ did not express their opinions regarding this question. However, all of them said we should respect our culture.

\section{Table 2: Summary of Teachers' Interviews}

\begin{tabular}{|c|c|c|c|}
\hline Question & $\mathrm{NR}^{2}$ & Percentage & Response and Reason \\
\hline \multirow[t]{2}{*}{$\begin{array}{l}\text { 1. What do you do } \\
\text { when your students } \\
\text { use Bangla in the } \\
\text { classroom? }\end{array}$} & 16 & $80 \%$ & $\begin{array}{l}\text { - Strictly prohibit Bangla } \\
\text { in the classroom. } \\
\text { - Give punishment for } \\
\text { this } \\
\text { - Reason: It is an } \\
\text { English medium } \\
\text { school } \\
\text { - They (the teachers) are } \\
\text { instructed like that }\end{array}$ \\
\hline & 2 & $10 \%$ & $\begin{array}{l}\text { - Do not do anything } \\
\text { (Do not give much }\end{array}$ \\
\hline
\end{tabular}

\footnotetext{
${ }^{2} \mathrm{NR}=$ Number of Respondents/Teachers
} 


\begin{tabular}{|c|c|c|c|}
\hline \multirow[b]{3}{*}{$\begin{array}{l}\text { 2. How do you } \\
\text { celebrate the } \\
\text { following days in } \\
\text { your school? When } \\
\text { do you think the } \\
\text { students enjoy } \\
\text { mostly? }\end{array}$} & & & care about it) \\
\hline & 15 & $\begin{array}{l}10 \% \\
75 \%\end{array}$ & $\begin{array}{l}\text { - Let them use Bangla } \\
\text { sometimes } \\
\text { - Students like Pohela } \\
\text { Boishak the most }\end{array}$ \\
\hline & 5 & $25 \%$ & $\begin{array}{l}\text { - Said about various } \\
\text { other occasions like } \\
21^{\text {st }} \text { February, } 31^{\text {st }} \\
\text { December, Friendship } \\
\text { Day, Pohela Falgun, } \\
\text { Valentine's Day, April } \\
\text { Fool, Christmas Day, } \\
1^{\text {st } J a n u a r y, ~} 16^{\text {th }} \\
\text { December, Eid-e } \\
\text { Miladun Nobi }\end{array}$ \\
\hline \multirow[t]{2}{*}{$\begin{array}{l}\text { 3. Which TV } \\
\text { programs do you } \\
\text { suggest your } \\
\text { students to watch? }\end{array}$} & 17 & $85 \%$ & 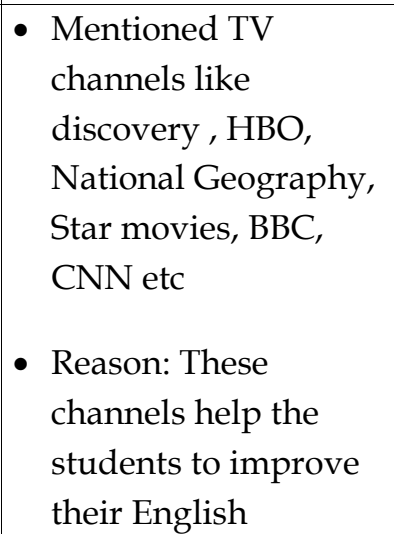 \\
\hline & 2 & $10 \%$ & $\begin{array}{l}\text { - The students should } \\
\text { watch which channel } \\
\text { they want to watch } \\
\text { - Sts. should watch }\end{array}$ \\
\hline
\end{tabular}




\begin{tabular}{|c|c|c|c|}
\hline & & & $\begin{array}{l}\text { Bangla channels to } \\
\text { know more about } \\
\text { Bangladesh }\end{array}$ \\
\hline \multirow{3}{*}{$\begin{array}{l}\text { 4. Do you co-relate } \\
\text { our cultural ideas } \\
\text { with that of foreign } \\
\text { countries? How? }\end{array}$} & 15 & $75 \%$ & - Do not correlate \\
\hline & 2 & $10 \%$ & $\begin{array}{l}\text { - They have the wish } \\
\text { but can not }\end{array}$ \\
\hline & 3 & $15 \%$ & $\begin{array}{l}\text { - Avoided the question } \\
\text { - Reason: It is very } \\
\text { difficult, time } \\
\text { consuming and } \\
\text { challenging }\end{array}$ \\
\hline \multirow[t]{2}{*}{$\begin{array}{l}\text { 5. Do you think the } \\
\text { students of EMSs will } \\
\text { face problem in } \\
\text { future if they know } \\
\text { little bangle? Why? }\end{array}$} & 16 & $80 \%$ & $\begin{array}{l}\text { Will not face any } \\
\text { problem, and } 2 \text { of } \\
\text { them }(10 \%) \text { said good } \\
\text { command over English } \\
\text { is very necessary for } \\
\text { most of the lucrative } \\
\text { jobs which knowing } \\
\text { good Bangla is not that } \\
\text { much necessary }\end{array}$ \\
\hline & 4 & $20 \%$ & $\begin{array}{l}\text { - The students should } \\
\text { learn Bangla properly } \\
\text { because it is their } \\
\text { mother tongue }\end{array}$ \\
\hline \multirow{2}{*}{$\begin{array}{l}\text { 6. What are your } \\
\text { opinions about the } \\
\text { changing trends in } \\
\text { Bangladesh }\end{array}$} & 14 & $70 \%$ & - It is very good sign. \\
\hline & 4 & $20 \%$ & $\begin{array}{l}\text { - Foreign influence is } \\
\text { not good }\end{array}$ \\
\hline
\end{tabular}




\begin{tabular}{|c|c|c|c|}
\hline $\begin{array}{l}\text { influenced by } \\
\text { western, Indian or } \\
\text { any other culture? }\end{array}$ & 2 & $10 \%$ & $\begin{array}{l}\text { - Did not express their } \\
\text { opinions regarding } \\
\text { this question }\end{array}$ \\
\hline \multirow[b]{2}{*}{$\begin{array}{l}\text { 7. Are you familiar } \\
\text { with the term } \\
\text { 'Cultural } \\
\text { Imperialism'? } \\
\text { How/From where? }\end{array}$} & 17 & $85 \%$ & - Do not know the term \\
\hline & 3 & $15 \%$ & $\begin{array}{l}\text { - Know the term but } \\
\text { cannot do anything or } \\
\text { reluctant to admit that } \\
\text { they have } \\
\text { responsibilities } \\
\text { regarding this }\end{array}$ \\
\hline \multirow[t]{2}{*}{$\begin{array}{l}\text { 8. Do you help your } \\
\text { students to be } \\
\text { familiar with western } \\
\text { culture? How? }\end{array}$} & 19 & $95 \%$ & $\begin{array}{l}\text { - They help, because it is } \\
\text { their duty } \\
\text { - They are supposed to } \\
\text { teach what is written } \\
\text { in the book }\end{array}$ \\
\hline & 1 & $5 \%$ & $\begin{array}{l}\text { - Disregarded the } \\
\text { question }\end{array}$ \\
\hline
\end{tabular}

Question seven was asked with the intention to check whether the teachers are aware of the process of how cultural imperialism was occurring. Most of the teachers (85\%) do not even know the term. The rest of the teachers $(15 \%)$ know the meaning of cultural imperialism but are reluctant to admit that they even have any responsibility to save our culture. Almost all the teachers said that they help the students to be familiar with western cultures because it is their duty and the books the students read were mostly about foreign cultures. They are obliged to teach what is written in the books. 


\subsection{Comparison between Teachers' and Students' Responses}

Based on the finding it seems that only a few teachers are aware of cultural imperialism; some of them are not familiar with the term directly but know something about it. But, comparatively it seems through the questionnaire survey that the students are not at all informed that they are becoming the victims of this vicious process, that is, cultural imperialism. The students read imported books written by western writers, which are prepared not based on Bangladeshi context. From the data, it was found that both the students and the teachers are reluctant to follow Bangladeshi culture.

Students' notion of Bangla language and culture in comparison with that of teachers in English medium schools is quite similar. Students practice socalled modern culture by following the western norms and traditions, and the teachers appreciate such practices. Based on the data, it seems as if students and teachers of English medium schools cannot be modern by following Bangladeshi customs, and therefore resort to western cultures. The teachers do not always make the students aware about Bangladeshi culture and tradition. Some teachers are conscious about cultural imperialism, but in reality, they hardly do anything to propagate their own culture. The findings suggest that most of the teachers believe, like their students, in the idea that anything imported from west is modern, and anything local is outdated.

In general, students of English medium schools seem to have very little idea about local culture. They tend to follow the syllabus set by their schools, and when the teachers and/or the schools do not try to make them conscious of local cultural practices, the students remain ignorant about such things and do not try to be informed on their own. The findings also suggest that even though some of the teachers have an idea about cultural imperialism they do not or sometimes, are unable to protect their students from the hegemonic powers of western culture in English medium schools. 


\subsection{Discussion and Recommendation}

It seems that the Bangladeshi culture is not being promoted in comparison with western culture. In the English medium schools, western culture seems to be predominating because they are presented in very attractive and appealing ways, Bangladeshi culture is being undermined. For instance, Christmas is associated with so many things like Christmas tree with colourful decorations, presents, mother Mary, Jesus Christ, Santa Clause, rain deer. On the other hand, though the two Eids are celebrated in Bangladesh, they are not glorified like Christmas or other western festivities in English medium schools. During the Eids the students only have vacations like any other vacations, but the school could tell the teachers to assign their students various assignments on Eid, its meaning, its significance, history and so on. The teachers should also explain that Eid is not a celebration for just eating rich food and buying new clothes; both of the Eids have deep-rooted significant meanings. It seems that English medium schools tend to shun local culture and embrace foreign culture, especially western culture. If the teachers were conscientious then they could at least help to make local culture more appealing and attract the students towards Bangladeshi writers and poets.

It is true that the students of English medium schools are reading western books, set in western context but if the teachers and the school authorities become a little concerned, they can help the students relate the foreign texts with the Bangladeshi context. Teachers have a vital role to play, because students tend to trust their teachers, sometimes more than their parents. Based on the findings of this study, it seems that most of the teachers are not very concerned about the protection of local culture and neither are the students of English medium schools.

\subsection{Conclusion}

Culture and language usually have a dialectical relationship; therefore, cultural imperialism goes hand in hand with linguistic imperialism. Though cultural imperialism is a much known term to the scholars, from 
this study it seems to be quite apparent that the schools, parents, teachers do not know much about it. There are many studies on cultural imperialism but hardly any research has been done on English medium schools. Therefore, this study is significant in contributing to the literature on cultural imperialism, particularly in English medium schools in the Bangladeshi context.

In English medium schools, the students are strictly prohibited from using any other language except English. As the students read books written by foreign writers set in western contexts, they become more informed about western culture than Bangladeshi culture. Based on the findings of this study, it seems that the English medium school authorities and the teachers tend to work hard to make their students good at English at the expense of Bangla language and Bangladeshi culture.

The schools in Bangladesh, whether English or Bangla medium, should educate the students in such a way that they (students) have a strong sense of 'self' and self-respect. Through this pioneering research, it may be assumed that the students of English medium schools are obsessed with western culture neglecting their own identity. Furthermore, the teachers and authorities of such schools also tend to implicitly foster cultural imperialism. The present situation of cultural imperialism in English medium schools in Bangladesh needs to be made aware, and gradually resisted or else there will be severe repercussions in the long run. Resistance against hegemonic cultural dominance is significant because the history of the Bangla language and Bangladeshi cultural heritage are at stake, which are often synonymously correlated:

Bangla is synonymous with Bangladesh, and imply that 'to deny the language is to deny the country'.

(Haque and Abedin, 2011, p. 388) 


\section{References}

Ainy, S. (2001). English Language Teaching in Bangladesh Open University: Changing Scenario. Journal of Distance Education, Vol. 8 (1), pp.112-121.

Al-Quaderi, G. (2010). English literature at English-medium schools of Bangladesh: the question of culture. Pedagogy, Culture $\mathcal{E}$ Society, Vol. 18 (2), pp. 211 -226.

Banu, R. and Sussex, R. (2001). English in Bangladesh after independence: Dynamics of policy and practice. South Melbourne: Oxford University Press, pp. 122-147.

Baugh, A. C. and Cable, T. (1993). A History of the English Language. London: Rutledge.

Canagarajah, S. F. (1999). Resisting Linguistic Imperialism in English Teaching. Oxford: Oxford University Press.

Chang, Y. (2004). How American Culture Correlates the Process of Globalization. Asian EFL Journal, Vol. 6, Issue 3, Article 4. Available at: www.asian-efljournal.com/Sept_04_cyc.pdf

Crystal, D. (1997). English as a Global Language. Cambridge: Cambridge University Press.

Ekushe, English and Ethics. (21 February 2010). The Prothom Alo, p. 13.

Haque, F. (4 October 2009). Engrezi madhom Biddapith nia kishu kotha. Prothom Alo, 13.

Haque, M. S (2011). Bridging the Gap between Academia and the Real World: An Exploratory Framework from Bangladesh. Proceeding, $3^{\text {rd }}$ International Seminar on Culture, English Language Teaching, and Literature, 2011, pp. 182-196.

Haque, M. S. and Abedin, Z. (2011). The discursive construction of (a)moral names: Religion versus language. Multilingua Vol. 30, No. 3-4, pp. 377-390.

Hasan, K. (2004). A Linguistic Study of English Language Curriculum at the Secondary Level in Bangladesh - A communicative approach to curriculum Development. Language in India Vol.4. 
Kachru, B. B. (1985) Standards, codification and sociolinguistic realism: the English language in the outer circle, in R. Quirk and H.G Widdowson (eds), English in the World: Teaching and Learning the Language and Literatures. Cambridge: Cambridge University Press, pp. 11-30.

Kachru, B. B. (1986) Non-native literatures in English as Resource for Language Teaching, in C. J Brumfit and R.A Carter (eds), Literature and Language Teaching. Oxford: Oxford University Press, pp. 140-149.

Kamol, E. (31 December 2009). Closing the Gaps, The Daily Star.

Modiano, M. (2001). Linguistic Imperialism, Cultural Integrity, and EIL. ELT Journal, Vol.55 (4), pp. 339-346.

Pennycook, A. (1994). The Cultural Politics of English as an International Language. Oxford: Oxford University press.

Phillipson, R. (1992). Linguistic Imperialism. Oxford: Oxford University Press.

Rahman, M., Hamzah, M. I. M., Meerah, T. S. M. and Rahman, M. (2010). Historical Development of Secondary Education in Bangladesh: Colonial Period to 21 ${ }^{\text {st }}$ Century. International Education Studies, Vol. 3. No.1

Tickoo, M. L. (2006). Language in Education. World Englishes. Vol. 25, No. 1, pp. 167-176.

Tomlinson, J. (1991) Cultural Imperialism: A Critical Introduction. London: Pinter.

Young G. M. (1957). Minute of 2 February 1835 on Indian Education. In G. M. Young, Macaulay, Prose and Poetry. Cambridge MA: Harvard University Press, pp. 716-29. 